\title{
VARIABILITY IN RIGHTS ENFORCEMENT: A COMPARATIVE PERSPECTIVE
}

Laurence Whitehead

\begin{abstract}
Resumo
O artigo aborda uma seleção parcial de muitos direitos reivindicados pelos cidadãos em democracias contemporâneas a respeito do sistema jurídico, segurança cidadã, gênero, jovens e acesso à informação - e apresenta o argumento de que "direitos" democráticos não são uma realidade homogênea como apresentada pela teoria liberal, mas um conceito complexo e multifacetado. Nas novas democracias de "baixa qualidade", a volatilidade de direitos apresenta-se como um desafio especial à universalidade. Um mapeamento social da variação e distribuição dos direitos negociáveis são passíveis de desvelar a realidade que cai na retórica do universalismo. Em sociedades altamente fragmentadas e desiguais, a retórica da universalidade é improvável de ser traduzida facilmente em aplicação da equidade verossímil. E a variabilidade que acompanha pode produzir instabilidade ou volatilidade por todo o tempo. Essa combinação em sociedades onde os "deveres"correspondem a direitos não são solidamente internalizados e é responsável por produzir modelos de comportamento político que desviam substancialmente da intersubjetividade do interesse postulado pelo liberalismo clássico. Ciclos políticos "contenciosos" de resistência e exclusão, e lutas para reformular as regras do jogo (em lugar de simplesmente viver nelas) parecem ser correlações naturais desse clima de incerteza. Isso é particularmente verdade em novas democracias, onde súbitas explosões de clamores de direitos e multiplicidade destes podem facilmente gerar uma atmosfera de inflação de direitos aumentando as expectativas além do que é provavelmente alcançável.
\end{abstract}

Palavras-Chave: Instabilidade de Direitos e Volatilidade; Novas Democracias; Democracia de Baixa Qualidade; Cidadania; Consciência Política.

\begin{abstract}
The article looks at a partial selection of the many rights claimed by citizens in contemporary democracies in the context of the justice system, citizen security, gender, youths, and access to information - and presents the argument that democratic "rights" are not a homogeneous reality as posited by liberal theory, but a complex, multilayered one. In new "low quality" democracies, rights volatility presents a special challenge to universality. Social mapping of the range and distribution of bankable rights is likely to uncover a reality that falls well short of the rhetoric of universalism. In highly fragmented and unequal societies, the rhetoric of universality is unlikely to translate easily into genuine evenness of application. And accompanying variability there may be instability or volatility over time. This combination in societies where the "duties" corresponding to rights are not securely internalised, is liable to produce patterns of political behaviour that deviate substantially from the interlocking mutuality of interest postulated by classical liberalism. "Contentious" political cycles of resistance and exclusion, and struggles to reshape the rules of the game (rather than merely to live within them) seem to be natural correlates of this climate of uncertainty. This is particularly so in new democracies, where sudden explosions of rights claims and multiplying rights claimants can easily generate an atmosphere of rights inflation can raise expectations well beyond what is reliably deliverable.
\end{abstract}


Key-Words: Rights Instability and Volatility; New Democracies; Low Quality Democracy; Citizenship; Contentious Politics.

\section{Comparing Rights Enforcement and Democratic States}

Every modern democratic state operates in a multiplicity of policy domains, and interacts with the citizenry through a wide diversity of agencies and institutions. This means that the ideal of "equality of rights" has to be interpreted, filtered, and transmitted through a huge array of channels, most of which are primarily focussed on much more specialist tasks, and are in direct contact with only small subsections of the total electorate. Thus, the police must uphold the ideal of an equality of right, while mainly concentrating on the control of crime and the maintenance of public order (not usually threatened by the median voter); the courts must dispense justice (for which purpose on underpinning of democratic theory - or at least assumptions - is highly desirable if not essential). But the great bulk of the population never even enters a courthouse. The schools may provide civic education to the young, but their main objective is usually to train a workforce rather than build a republican consciousness. The same applies, for instance, to the tax administration and the consumer protection agency. Only the electoral registration agency is charged with directly promoting and protecting the democratic rights of all citizens, and is expected to achieve universal coverage in the fulfilment of that task. Other instruments of democratic socialization operate in a restricted front and perhaps only at a local level (such as safe drinking water and street lighting for all).

Similarly, from the perspective of the citizenry democratic rights are complex, diverse, fragmented, and perhaps even incommensurable. I have a right to the vote (provided I meet the specified age, nationality, residence and criminal and mental status criteria, which can vary widely from democracy to democracy - an automatic right in Costa Rica, one requiring registration and perhaps even a driver's license in the U.S.A., to give just two examples). In Britain, I have a right to freedom of 
information (but subject to the Official Secrets Act, plus whether other bureaucratic or market-derived barriers may limit the practical application of that ideal). I also have a right to privacy (except that if a democradura wishes to practice surveillance, perhaps to protect our freedoms from terrorist assault, then this right can be extensively curtailed). Even my right to life can be qualified (if the Metropolitan Police happen to mistake my trousers for a suicide belt, for instance). Certainly my right to education, to healthcare, even to habeas corpus, can be qualified and hedged.

Since all of these rights are to some extent subject to qualification or temporary suspension, I can only hope to enjoy the full panoply of my rights by monitoring them and by challenging attempts to infringe them. But in modern society no individual will get very far in challenging authority on her own - collective action and community support are always required to define, defend, and promote our democratic rights. "Take it on trust and you will be taken and trussed". Moreover, there are evident tensions and indeed conflicts between the various potential contenders as "trumps" in the rights game (the right to information versus the right to privacy; the right to protection from crime versus the presumption of innocence, and so on). Some rights are legally enforceable entitlements; some are universally grounded moral convictions; some are passionately advocated and equally passionately resisted; and some are aspirations rather than solidly established expectations. Finally, in unequal societies, the objective and subjective distribution of rights (whether as entitlements or as aspirations) is uneven between classes, races, regions, age cohorts, and genders.

According to a standard liberal view of rights every rights claim must be attached to individual claimants, and each claim by one individual generates a counterpart duty to meet that claim that falls on other individuals. But such precision and individuation is an ideal construct quite far removed from the everyday life experience of most citizens, even in the best established of democracies. Elsewhere and particularly in new democracies where such rights claims have not been 
collectively internalized, individuals and groups have every incentive to overstate their claims and to sidestep the correlative duties.

The considerations in the above paragraphs apply to all really existing modern democratic states, even to Sweden and Canada. How much more do these complications muddy the waters in the relatively "low quality" new democracies that are more typical of the western hemisphere today? Elsewhere I have argued that for much of the population in most Latin America and Caribbean democracies their theoretical "rights" are perceived as patchy and unstable (WHITEHEAD, 2004). In the democracies where "quality" is most subject to questioning, the scope and coverage of rights is characteristically unstable and volatile. A certain minority may feel reasonably secure in all of their rights. A possibly equal sized minority may be absolutely clear that such rights are not extended to themselves, but in between lies a wide array of citizens who cannot be sure. On good days they can claim some rights, especially if they agitate. If they stay passive, or if their system is subjected to some shock, rights that seemed to be assured can abruptly evaporate. Their pension fund can be seized and allocated to pay off foreign creditors. Their access to information can be abruptly curtailed by censorship or manipulation. The leaders who seemed accountable to them can with short notice turn into inaccessible autocrats or irresponsible incompetents. Experience teaches that as a rule rights are not stable and cannot be taken for granted; rather, they are volatile. But this in no way undervalues the importance of generating such rights. On the contrary, those citizens who feel most insecure in their entitlement to rights have the most to gain from collective reiteration of such aspirations. Therefore it is assumed (both by citizens and by those in positions of state authority) that theoretical entitlements will only be made "real" from time to time and under pressure from outside the state. The demand for an extension of rights may be particularly explosive in societies where the corresponding traditions of "dutifulness" are least well entrenched. This volatile climate of expectations helps to explain the widespread incidence of various forms of "contentious" politics (road blocks, tomas, multiple forms of 
street protest, and so on), which may be viewed as partially democratic both in intention and even in effect. Those whose theoretical rights are not secure can argue that they are agitating not only for their own interest, but for a more systematic delivery on these official promises to everyone. But, in practice, the best organised and most strategically located groups may only succeed in extracting concession from the state that serve their narrow group interest, while indirectly weakening its neutrality and authority to promote the rights of all, and indeed diverting its energies from the needs of the marginal and disorganised. Within this very broad interpretative framework, it should be possible to advance comparative research on democratic rights by collating the evidence available from a series of distinct sources sectors, and policy domains.

\section{Rights and Justice Systems}

For example, there is an emerging body of comparative work on the observable performance of courts and justice systems, as they interact with their particular stratum of subjects and citizens in these new democracies ${ }^{1}$. One such study, finds somewhat surprisingly, "that

social rights have been enforced most readily in new or
fragile democracies, where the judicial branch has
typically not had the time to build the legitimacy
required to survive political conflict, and where the
resources needed to implement social rights are
typically fewer than elsewhere" (GARGARELLA,
DOMINGO and ROUX, 2006, p. 256).

It turns out that where the resources for social protection are the most inadequate, and where the authority of the courts is most precarious, these may be the most favourable conditions for using the judiciary to keep alive the hope that eventually minimum social entitlements may prove generalisable; and that legal entrepreneurs may mobilise this potential as a means to strengthen their otherwise precarious institutional base. These case studies point to "the emancipatory potential of the law and the appropriation of language of

\footnotetext{
${ }^{1}$ One up-to-date survey and evaluation of the rise of justiciable social rights in new democracies since the end of the Cold War is by Gargarella, Domingo and Roux (2006).
} 
rights [when] courtrooms become an arena for political battles framed in the language of rights and constitutional entitlements" (GARGARELLA, DOMINGO and ROUX, 2006, p. 269). They suggest "a sort of 'discovery' of the law and legal channels from below by citizens that are more aware and demanding of their rights, and with changing expectations of what can be achieved through strategies of legal mobilization" (GARGARELLA, DOMINGO and ROUX, 2006, p. 269)². At the same time, they acknowledge at least two crucial limitations to relying on justiciable social rights as a means to strengthen the social foundations of fragile new democratic regimes. They acknowledge the "selection bias" in their choice of case studies (Brazil, Hungary, and India, many be unrepresentatively favourable examples, although Angola, Bolivia and Colombia are also included, and exemplify various types of limitation). More critically, they stress that courts alone are unlikely to produce a great deal of social change - only if their effects are reinforced by other institutions, such as the executive, the legislative, the political parties, and local administrations are these aspirational shifts likely to be transformed into reliable expectations I would add the further caveat that the successful judicialization of social rights could normally be expected to induce its own antidote. Over time, if the courts prove more authoritative than expected and more capable of allocating scares resources, it would be reasonable to anticipate that more privileged sectors of society would begin to pursue their own interests through legal channels, in competition with the poor. In general, it would be prudent to expect that the better off will normally be best placed to turn such machinery to their advantage, and that legal entrepreneurs have more to gain from servicing the elites than from catering to the dispossessed. At a minimum one might foresee contentious politics and instability of rights as a medium term outcome of the judicialization of social entitlements, particularly where the poor can be divided by language, religion, caste, region, and so on. However that may be, we have here a highly researchable topic for comparative investigation

2 The authors credit the United Nations Development Programme (UNDP) Human Development Reports with a role in sensitizing actors to this potential.

REVISTA DEBATES, Porto Alegre, v. 2, n.1, p. 33-50, jan.-jun.2008. 
within the broader field of "democratic citizenship" studies.

\section{Rights and Citizen Security}

Citizen security provides another quite specific and empirically researchable area of comparative study within this overall context. It is, in principle, a fundamental responsibility of any democratic state to provide at least a minimum level of personal and collective security to the whole of its citizenry. Many would argue that the state itself rests on an underlying social compact, whereby subjects relinquish some of their freedom of action (accept the responsibilities of citizenship) in exchange for credible assurances of state protection. Should the state fail (or abdicate from) its role as provider of security then its subjects, following the inescapable logic of self-preservation would be released from these restraints and entitled to save themselves by other means. According to this reasoning the democratic state extends additional guarantees to its subjects (they become citizens, with civil and political rights as well as an entitlement to state protection) and secures additional levels of cooperation in return. Citizens owe cooperation rather than just acquiescence; they gain protection from abusive treatment (dignity) as well as the right to survival. Foucault presents this as an internalization of restrains that were hitherto outwardly imposed, so that the art of government becomes that of both guaranteeing the liberty of the citizenry and also of manufacturing it at each moment. So for him the democratic authorities must continually produce, maintain, and also limit the freedoms exercised by their citizens, and must allocate the costs arising from this public activity ${ }^{3}$. On this view, the production of liberty is indissolubly linked to the manufacture of danger. This perspective may help us understand the current apparent paradox of western democracies rushing to establish heightened surveillance and curbs on traditional freedoms, in order to counter what is described as existential threat to democracy arising from "terrorism." The democratization

\footnotetext{
${ }^{3}$ For a fuller discussion see Whitehead (2002, p. 167).
} 
literature has coined a term for this kind of highly constrained democracy: democradura ${ }^{4}$.

But at least in many recent and fragile democracies - and notably in Latin America and the Caribbean - the starting point for this type of analysis is open to question. Does the Colombian or Salvadoran state currently provide a minimum level of personal and collective security to the whole of its citizens? Although these may both be qualified as broadly "democratic" states, plenty of ethnographic evidence exist to indicate that a large section of their electorates have to turn elsewhere for their self-preservation (to the cruel protections provided by local paramilitary forces, or guerrilla movements, or mara youth gangs). Even the official agents of the state - the police, the military, the courts - may be far more effective in manufacturing danger for the citizenry than in upholding any kind of public freedoms. The evidence on this is increasingly standardised and available in comparative format (homicide rates, proportions of internally displaced persons, kidnapping figures, rates of impunity for crimes denounced to the authorities, and so on). The evidence suggests large variations between countries, within different parts of the same country, and over time. More fine-grained comparison often indicates high levels of complexity and ambiguity.

In many new democracies there are highly differentiated systems of collective security, they are unstable, and they overlap. Thus, from a "bottom up" perspective to judge what guarantees one can rely upon requires much finer discriminations than simply "the state" versus "the mafia". The precise location, the time of day, the informal conventions of the locality, may be far more critical then any abstract system of reassurance or guarantees, either from state agencies or from poderes fácticos. Some elite sectors of the population may live in gated communities, protected by private security forces, and mostly sheltered from the uncertainties affecting the citizenry in general. At the other end of the scale, the most vulnerable may have no realistic prospect of

${ }^{4}$ The Primo de Rivera dictatorship in Spain became known as a "dictablanda." In the 1970 s the Uruguayan superficially democratic government of J.M. Bordarberry earned the reverse sobriquet "democradura" and both concepts were then generalised. 
obtaining any kind of public protection under any circumstances. But most - unusually a large majority of the democratic electorate - are likely to be strung out between these two extremes. They can neither rely upon their social compact with the democratic state, nor disregard it. It has to be factored in as an aspirational claim, a potential entitlement, and an occasional resource. But it cannot command exclusive allegiance from most citizens, because it does not reliably protect them from most threats to their physical security. More precisely, many citizens in these new democracies do not perceive the official security and justice systems as trustworthy first lines of defence against basic insecurities.

There are various - perhaps cross-cutting - responses possible here, including demanding police reform or mano dura, protesting against state failure in this area, turning to alternative sources of protection, or (quite commonly) relying on personal survival strategies that weaken collective solidarity. For their part, the democratic authorities have to cope with this public distrust and these legacies of state failure. They may sometimes devise incremental strategies for regaining lost ground and building conventional democratic authority. But they may also fall back on short-term expedients that only reinforce long-term perceptions of their unreliability. Or they may practice large scale denial - deploying an official discourse that pretends they are fully in control, while only in practice acting to protect their most limited core institutions and constituencies. Just as the most typical response of the median citizen may be salvese quien pueda survival strategies that weaken collective solidarity, so at the state level the line of least resistance may well be to remain reactive and thus allow the prevalent insecurity to persist. The result is likely to be an unstable equilibrium, or as O'Donnell (1993) has written elsewhere, "a low intensity" citizenship.

Comparative research on citizen insecurity in new democracies is now underway. It tends to disaggregate this overall picture into a series of more discrete and manageable sub-themes - victimization rates; economic losses attributable to insecurity; access to illegal firearms; and so forth. This empirical mapping is indispensable, but the various 
components of the analysis must then be reconstituted into an integrated account if we are to understand their implications for citizenship rights and the prospects for democratization. A historically based and interpretive synthesis is required for each society in order to assess the realistic possibilities for reform. Existing academic studies of police and justice system reform tend to produce accounts that "over determine" the likelihood of failure. By contrast consultancy and policy studies tend to build in "can do" assumptions into their analysis. The comparative record casts doubt on both these perspectives.

Careful comparative work on the reform and reinforcement of police and penal systems in new democracies should caution us against categorical judgements. There certainly is a great deal of underlying inertia. Policing is mostly carried out by small groups of officers subject to strong peer group pressures and resistant to anything more than incremental changes in their informal assessments of the very localised conditions they have to deal with on an intimate and daily basis. Similar considerations restrict the scope for rapid change in the behaviour of prison officers. Where police and prison officials have become accustomed to operating under authoritarian leadership, the installation of a new democracy with a bill or rights and a human rights commission can not be expected to feed through automatically to changed official treatment of suspects and detainees. These aspects of the predemocratic state structure are often among the last to be modified in the case of democratization. It is not unusual for traditional methods of policing to persist in general (although middle class and educated dissidents may no longer be mistreated so badly as common criminals), and for many in the security forces to view the new human rights activist community as their enemies. Despite this general resistance and inertia however, other patterns of response can also be noted. In some instances the newly created civil rights monitoring agencies have won co-operation from the security forces for example by emphasising the point that police and military personnel also have human rights that need to be protected. One striking positive example was the - fairly rapid and successful - transformation of the East German Stazi into a 
fairly normal West German type of police force. Less extreme cases include the professionalization and rejuvenation of personnel in the Chilean justice system after 1989; some examples of provincial-level progress even within systems that remain unimproved at the national level; and intermittent instances of effective foreign assistance to promote more democratic policing. The record is very patchy and for each example of improvement it is also possible to identify a counterexample of failed reform or even regression. Nevertheless, it demonstrates that under certain circumstances new democracies can upgrade their justice systems.

Building democratic security and citizen confidence in public authority is certainly difficult, and may be brought about more by indirect means than by conscious social engineering. But there are important examples of cumulative improvement, as well as of failure and indeed degeneration. With longer time frames and better evidence comparative research may in due course generate more reliable knowledge.

\section{Gender and Rights}

A well-developed feminist critique of the conventional discourse of rights points out the contrast between the (usually male dominated) public sphere in which such entitlements can more easily be claimed and defended and the (often gender-biased) private sphere in which conflicts of interest are regulated by informal mechanisms that may well be governed by personalised reciprocity and indeed structured by patriarchy. Without entering into the details of this critique, or exploring the several conclusions it could generate concerning how to define and promote women's rights, the point to note here is that even in the most secure and well-established democracies there is an ongoing gender imbalance that qualifies the abstractions of liberal rights discourse. In new democracies, with saturated labour markets and socially/geographically uneven levels of development such gender imbalances may well be far more extreme and may pose a more frontal challenge to assumptions about the universality of individual rights. The 
religious and cultural dimensions of these imbalances are currently at the forefront of public debate in many democracies but the challenge is not merely about such issues. Huge inequality can often be observed between highly educated women (with the full panoply of rights at their disposal) and their live-in maids, informal street vendors and the rest. Yet rich or poor, rights bearing or subordinated all women perform essential tasks of child-rearing, household-sustaining, and valuepromoting that are core activities for the formation of a rights consciousness in any democratic society. It is in principle possible to establish universalistic public policies that address this issue (e.g. Brazil's Bolsa Familia) but in this area much remains to be done. This brings us to the topic of rights and young people.

\section{The Rights of Young People}

In conventional liberal theory young people have "guardians" who encourage their self-expression of development, but who also exercise rights on their behalf. Thus the vote may be limited to those aged 18 and above, as may the owing of property, the opening of bank accounts, perhaps the decisions to marry, and maybe (theoretically) even the decision to commence sexual relations. Yet in practice (and data can be assembled to develop this point) a very large proportion of the world's young people are not being schooled in their liberal rights and obligations as suggested by this schema. They may have no real guardians, or the adults with legal responsibility for them may be too poor or vulnerable to look after them at all (if they cannot look after themselves they have to press their wards to take on adult responsibilities prematurely). Youths even be exploited rather than protected by the adults who have nominal responsibility for them. Or they may retreat into adolescent gangs that turn their backs on adult society, and provide their own brutal alternatives to the conventional sources of socialization (via schools, youth clubs, churches, and so on). They may even become child soldiers (mostly male) or be trafficked as property (especially if female). Certainly, by comparison with the seven basic rights of the children that United Nations Children's Fund 
(UNICEF) would like to see universally respected, many of the world's young people are experiencing neglect, abuse, defencelessness, and perverse indoctrination. This is partly just an expression of poverty, but it is not that simple. Some poor traditional communities are adequately socialising and even protecting their young. Many more economically dynamic and "successful" societies are building their prosperity on the unsound foundations of family disintegration, school failure, international undocumented migration, and "savage" market relations. Our understanding of the social correlates of alternative development paths requires careful tracking and mapping of this complex and unstable panorama.

But even if the young are trained through family, school, and church or sports club to internalize all these postulated adult values, they still have to undergo a long, tortuous, and somewhat uncertain process of learning and adjusting to conform to their minimum grown up obligations. They have to find jobs, form stable relationships, manage their own resources, secure respect within their peer groups, and fend off all kinds of temptations and dangers. Still, according to standard liberal theory most of them can be expected to manage this adequately in due course, and all kinds of provisions are in place to discipline or reeducate the backsliders (bankruptcy laws, social workers, police, and prisons). Contrast this idealised picture with the models of adult behaviour available to so many (perhaps a majority) of the world's young people, especially in big cities, in recently democratised polities and marketised economies, and in the many crisis-torn or even "failed" states of the so-called developing world. Not only are the supportive structures of adult liberal society often lacking, but unprotected youth accurately perceives that what awaits them on adulthood is a system of incentives and constraints that contradict the rhetoric of universal rights and good governance. Only the innocent or the protected offspring of the privileged classes can be expect to take that discourse at face value. For many (perhaps most), young adults entering the legal status of full individual autonomy, the negative lessons of adolescence are all too likely to be reinforced by their lived experiences of insecure 
employment, unstable household formation, and (non) participation in the public sphere.

If the under $18 \mathrm{~s}$ do not vote then democratic politicians will relate to them in a different manner from adults who do. Public policies directed at the young may tend to view them more as "objects" of administration (numbers to be fed, bussed, or schooled) rather than as rights-bearing citizens. In addition state administrators (democratic or not) may typically try to reach them through intermediaries (parents, teachers, police officers) rather than directly. And in many societies, young people will find they have been stratified for administrative purposes, (by race, gender, class, regional origin, among other categories) long before they have been given any opportunity to express themselves, or even to develop a sense of their own identities and aspirations. All this poses a serious challenge to the prevailing orthodoxy about what they are entitled to expect from the state, and what the state can expect from them.

According to the idealised liberal theory that underpins standard exhortations to ensure "transparency," "accountability," and "respect for the rights of others," the adult world either is, or ought to be, populated by responsible and civically aware citizens. But where do these essential actors in any liberal society come from? They are constantly recruited and replenished from the ranks of this youth population, whose socialization experience is all too often at variance with these principles of adult responsibility and civility. Consequently failures of socialization at the pre-adult level readily feed through into instabilities and incapacities to stabilise the rights theoretically assigned to all adults in a liberal democracy. Weakened family structures and ineffective schooling thus reproduce rights volatility and variability across the generations.

\section{Rights and Access to Information}

Another fundamental attribute of democratic citizenship concerns the so called "right to information." In practice, of course, even in the most secure and liberal of the old democracies, this so called "right" is hedged around with limitations and qualifications. There is the 
information required to conduct dialogue and deliberation in the public sphere. But there is always a large area of "insider" knowledge - official records that are classified as secret; unofficial background information that puts the official record into the perspective required to decipher its true significance; hidden interpersonal and financial data that could reveal the base motives that sometimes drive decisions ostensibly taken in the public interest; and there is always also a second large area of private, personal information that can be deemed irrelevant to the public sphere. How these boundaries are drawn (and periodically redefined) is a recurrent theme in democratic politics. Given the "grey areas" involved, and the shifting dynamics of public confidence in all large scale political systems it is not surprising that the limits to public information are typically contested and subject to variation, both over time and between democracies. Nevertheless the twin concepts of citizenship and the democratic state rest on the assumed existence of a relatively large and secure public sphere, within which different conceptions of the collective interest can be debated and chosen between on the basis of a shared repertoire of public knowledge.

However, in many new democracies the stability and scope of this public sphere is far from being a given. The dominant news media may well have a long track record as defenders of the pre-democratic order (such as El Mercurio in Chile, or Televisa in Mexico). Journalists and newscasters may have been trained and promoted on the strength of their ability to promote official discourse, rather than because of their critical or investigative skills. State controlled media may continue these bad old practices; private and privatized news media may serve the interests of their owners and advertisers rather than of the new democratic system. Voters and citizens may find it difficult to discriminate between genuine public information, disinformation, and comforting propaganda. The Habermasian ideal of unfettered communicative interaction (HABERMAS, 1987) is probably too intellectualised, and too demanding of the attentions of the median voter, even in the most highly educated and politicised of "really existing" democracies. In fragile new democracies this public sphere is 
likely to expand and contract quite unpredictably and generally to operate at an uneven and inadequate level of reliability. This will reflect the inherited legacies of the pre-democratic era, the incomplete and unequal qualities of citizenship established, and the problems of state authority and public policy formation outlined elsewhere in this article. Of course, not all new democracies are equally afflicted, and it is certainly possible to trace some heartening experiences of rapid progress in building a culture of pluralist public deliberation where censorship and orthodoxy previously prevailed (the Portuguese weekly Expresso, for instance, played a remarkably constructive role in this sense in the 1970s; and a comparative analysis could map and trace an impressive range of analogous experiences elsewhere - although they might often prove time limited and restricted to a small segment of the total electorate).

In general, however, the citizenry of most new democracies has to make its leadership and policy choices, and to interpret its ongoing political realities, on the basis of public information that falls drastically short of what would be required by most theories of transparency and accountability. The "right to information" enjoyed by most voters in new democracies is even more constrained, distorted, and subject to reversal than is the case in long-established democratic regimes. Here too, a "quality of democracy" analysis that seriously ranks and compares the communications performance of governments, media, think tanks, and the like in different new democracies would be likely to uncover large inter-country and inter-temporal variations, together with great differences between regions and social strata. As with the other spheres of citizenship reviewed in this brief article, instability and unreliability are often key watchwords. Where this becomes apparent, it may sow popular distrust and citizen disillusion, although it can also serve as a spur to corrective reforms

\section{Conclusions}

In the space available it has only been possible to comment on a partial selection of the many rights claimed by citizens in contemporary 
democracies. The complete ensemble would also need to include more social rights; environmental protections (including the rights and duties associated with inter-generational transfers); the rights of refugees and internally displaced persons; the rights of the aged; and perhaps some collective rights claimed by ethnic and religious minorities and other discriminated-against groups. The language of rights can be applied in all these areas and wherever it is adopted the implication of this discourse will be that such rights need to be universally applied and need to be given precedence over more partial and self-serving claims. This paper is not an attack on the moral or philosophical basis of such claims nor is it intended to belittle the beneficial consequences that can follow from their adoption. It is, however, a reminder of the sociological reality that in highly fragmented and unequal societies the rhetoric of universality is unlikely to translate easily into genuine evenness of application. Also, in new democracies emerging from authoritarian regimes, the sudden emerging explosion of rights claims and the abrupt multiplication of rights claimants can easily generate an atmosphere of rights inflation that may stimulate activism and social anxiety, and this is liable to raise expectations well beyond what is reliably deliverable. For all these reasons, social mapping of the range and distribution of bankable rights is likely to uncover a reality that falls well short of the rhetoric of universalism. Especially in new democracies this empirical variability may be accompanied (for most citizens) by a considerable degree of instability over time ("volatility"). The combination of variability and volatility in societies where the "duties" corresponding to rights are not securely internalised, is liable to produce patterns of political behaviour that deviate substantially from the interlocking mutuality of interest postulated by classical liberalism. "Contentious" political cycles of resistance and exclusion, and struggles to reshape the rules of the game (rather than merely to live within them) seem to be natural correlates of this climate of uncertainty. All this may well be reinforced by the growing impact of "globalization," which generates diasporas and transnational communities that further challenge universalism and established rights. 
Laurence Whitehead is Official Fellow in Politics at Nuffield College, Oxford University, and Senior Fellow of the College.

E-mail: laurence.whitehead@nuffield.ox.ac.uk

\section{References}

GARGARELLA, R.; DOMINGO, P.; ROUX, T. Courts and Social Transformation in New Democracies: An Institutional Voice for the Poor? Aldershot: Ashgate, 2006.

HABERMAS, J. Teoria de la acción comunicativa. Madri: Taurus, 1987.

O'DONNELL, G. On the State, Democratization and Some Conceptual Problems. World Development, Montreal, v. 21, n. 8, p. 1355-1369, aug. 1993.

WHITEHEAD, Laurence. Democratization: Theory and Experience. Oxford/UK: Oxford University Press, 2002.

WHITEHEAD, L. Notes on Human Development, Human Rights and Auditing the Quality of Democracy. In: O'DONNELL, G.; CULELL, J. V.; IAZZZETTA, O. M. (Eds.). The Quality of Democracy: Theory and Applications. Notre Dame: Notre Dame University Press, 2004. p. 176187. 